\title{
ENGLISH FOR SPECIFIC PURPOSES: TEACHING ENGLISH FOR SCIENCE AND TECHNOLOGY
}

\author{
I. A. Musikhin \\ Siberian State University of Geosystems and Technologies, 10, Plakhotogo Str., Novosibirsk, 630108, Russian Federation - \\ igor_musihin@mail.ru
}

Commission VI, WG VI/4

KEY WORDS: English for specific purposes, Needs Analysis, Teaching Methods, Selection of Materials, Development of Manuals, Didactic Approaches

\begin{abstract}
:
In the era of globalization, English communication for scientists and engineers whose native language is not English has become as important as their major related abilities. The paper describes the results of a four-year experience in the development of English for specific purpose manuals in the field of photogrammetry, interferometry, and GNSS technologies, as well as key teaching methods and didactic approaches used in class and out-of-class activities. The focus of the present study is to provide a detailed description of the development and systematic updating of a relevant manual, aimed at professional language training of learners. The findings of the study reflect the importance of an ESP course for scientists and engineers: conducting a needs analysis for carrying out a specific search of relevant and reliable authentic materials, defining proper teaching methods, software and didactic approaches used in the educational process to develop the language skills necessary to be active and contributive players in the competitive world.
\end{abstract}

\section{INTRODUCTION}

English, as the lingua franca of international communications in all fields of human activity, is so widespread that now it can be considered as an Asian language (Bolton, 2008). However, the importance of English is not just how many people speak it, but what it is used for (Kitao, 1996).

Due to the constant and rapid developments, taking place in science and technology, most of the traditional models of language education have become extremely inadequate to meet the challenges of the present day's demands and practices of the academy in the world of professions.

Recent research clearly favours a model of English for specific purposes (ESP) that focuses on the acquisition of professional expertise, which integrates disciplinary knowledge and professional practice in a complex and dynamic manipulation of different social situations within which most forms of specialized communication take place.

Up-to-date technologies and scientific ideas continue to be exchanged all round the world. In this line it is imperative that engineers and scientists, including graduates of technical universities, to develop the language skills necessary to be active and contributive players in the competitive world.

As the language competence needed by engineers and scientists should be related to their professional field there is no longer need to ask if their English language skills must be improved, the question is how teachers should go about improving these skills (Talberg, 2006), allowing learners to perform a fullfledged communication in the typical situations of their professional activity. Thus, as the language competence needed by scientists and engineers should be related to their professional area, a language learning approach should be based on the activities that are relevant and typical to their profession in an international context. A language learning program will therefore have to improve not only the language skills as such, but will also have to enhance their comprehensive awareness enabling learners to communicate adequately with colleagues from other countries.

The university we present historically specializes in training students in such fields as geodesy, photogrammetry, remote sensing, cartography, aerial and satellite survey, geomatics, geomonitoring, cadaster, ecology and environmental management as well as a number of other ones, lying far beyond geospatial and into other disciplines. Our research on specific needs of graduate and postgraduate students in the field of language competence, related to their professional activities, showed a great interest of the latter in a significant improvement of their language skills.

Due to this fact we started our search for advanced language learning practices focusing on the development ESP manuals, enabling learners to improve and master their language skills within a relatively short-term training course.

According to Ono and Morimura (2007) within an ESP course it is important learners acquire:

- An English proficiency which will allow them to communicate with English-speaking specialists all over the world

- A cosmopolitan, global outlook

- Experiences which will enable them to communicate with other nations on equal terms outside their own country

- Creative skills and self-motivation for exploring solutions to problems related to their professional domains

- An appreciation of diverse cultures in the world.

On this background it was decided to develop several ESP courses based on the fundamental principle that we can identify a set of core language needs of target learners, adopt teaching materials and practices that will facilitate learners to meet their needs.

The focus of this study is to introduce a comprehensive technology to the development and updating of ESP manuals and means of technical support as well as teaching methods used in the classroom, which would allow an efficient language 
training of all third parties in the field of their professional activity.

The whole course syllabus of the developed manuals is designed for 72 hours of classroom activities and approximately 68 hours of independent out-of-class work and is intended for those learners (mostly academic and research staff, graduates, and $\mathrm{PhD}$ students) who have basic knowledge of English and are able to solve their communicative tasks using GE (CEFR: levels A2 - B1).

Since 2012 the latter settings have been implemented in the educational process of our University and proved to be both time and cost efficient. For this study, three research tools as questionnaires and target group interviews, classroom observation, and analysis of scientific literature have been used.

\section{DEVELOPMENT OF AN ESP MANUAL}

With the constant and rapid evolution in science and technologies no manual for professional language training is perfect. However, it is considered the most powerful and efficient resource in achieving goals in terms of learner needs (Ono \& Morimura, 2007). The goals and objectives of main course syllabus are supposed to be reflected in the manual for professional language training. In this sense the manual does not determine its own aims in the professional area of a learner, but should provide the most appropriate lexis, set of language exercises, and technologies of learning a foreign language enabling specialists to perform a full-fledged communication within international cooperation.

That is why the key target of an ESP course should be twofold: to develop the learners' overall communicative competence in the field of their professional activity, and to lay the foundation for further learning and refinement of language skills. In this respect the learning targets, choice of study material, didactic approaches and syllabus should be relevant for the learners' field of study. At the same time teaching English to specialists is a delicate and demanding matter in terms of content, methods and techniques (Riemer, 2002), which requires the development of a special course where English is used as a kind of mediator. Basically, it is impossible to use a particular textbook without the need for updates and some supplementary materials, especially when its content becomes outdated every two or three years. In this context, when developing a manual for specific purpose language training, one of the basic objectives is the choice of proper study materials representing the current state of art that are taken from a variety of reliable and valid sources, primarily consisting of authentic texts, and preferably written by native English speakers (Talberg, 2006).

The course should be tailored to meet specific needs of learners on the basis of needs analysis which will identify what learners will be required to do with the foreign language in the target situation and how learners might best master the target language during their period of training (Kim, 2013).

Long (2005) and Kim (2013) name 5 sources for need analysis in ESP: published and unpublished literature, teachers and applied linguists, domain experts, learners, and triangulated sources. Among these Long (2005) strongly suggests using triangulated sources when the data is received from more than two sources. While working on our ESP manuals we consulted with professors and experts representing target domains for advice on English language needs of the potential learners, lists of relevant literature and web-sites (Porcaro, 2001; Tasić, 2009; Kim, 2013) in order to select up-to-date materials and cuttingedge research to be included into the ESP manual.

Since the manual is developed for specific purposes (to present learners actual lexis, improve their skills in translation, both from English into a native language, and what is much more important from a native language into English, oral communication and academic writing) it is essential to supply the manual with a sufficient number of professional authentic texts and academic papers both in English and native languages. When developing a manual it is also necessary to keep in mind that most of the learners do not like English classes: some have already become recognized and certified specialists who are usually not able to find a lot of extra time for visiting regular lessons and may leave the training course if the progress cannot be achieved immediately; others had a bad experience with learning a foreign language earlier or have not learned it at all. That is why at the initial phase of the ESP course teachers should value 'successful communication' more than 'grammatically accurate communication'(Ono \& Morimura, 2007) and remember that academic journal articles are too difficult for learners, especially in terms of content, which ought to be simplified and customized.

To motivate learners to master ESP the selected texts should be divided into three groups: general information about the subject, theoretical background, and applications. Then the first group of the texts needs to be adapted and simplified to make the introductory part of the manual not too difficult in the very beginning of learners' study.

Before undertaking the development of a manual, it is strongly recommended to carry out a needs analysis (NA) to identify what learners will be required to do with the foreign language in real-life situations and how they might best master the target language while their training (West, 1994). In our NA we used focus group interviews, questionnaire surveys, and analysis of scientific literature on ESP to specify the importance of the context in ESP training, see Table 1.

\begin{tabular}{|l|c|c|c|}
\hline $\begin{array}{c}\text { Respondents and } \\
\text { sources }\end{array}$ & $\begin{array}{c}\text { Conversational } \\
\text { English }\end{array}$ & $\begin{array}{c}\text { Goal } \\
\text { context }\end{array}$ & $\begin{array}{c}\text { Business } \\
\text { English }\end{array}$ \\
\hline $\begin{array}{l}\text { Published } \\
\text { literature }\end{array}$ & $47 \%$ & $38 \%$ & $15 \%$ \\
Domain experts & $34 \%$ & $51 \%$ & $15 \%$ \\
Research & $22 \%$ & $69 \%$ & $9 \%$ \\
associates & $34 \%$ & $65 \%$ & $1 \%$ \\
Learners & $34 \%$ & $56 \%$ & $10 \%$ \\
Average & & & \\
\hline
\end{tabular}

Table 1. The importance of the context in ESP training

According to the results of the NA, a relatively large proportion of the responders agreed that the primary focus, the developers of the manual should take into account, was the context (56\%) and conversational English (34\%).

The second most crucial decision is the one concerning the exact proportion of many constituents needed for the development of a successful ESP manual and just how much general English (GE) and ESP bring into the manual largely depends on many conditions, e.g. level of learners' language training, NA results, period of training, etc. Therefore, the first group of texts needs to cover all of the basic grammar units and language skills before proceeding to the other parts of the ESP manual (Tasić, 2009).

Thus, in line with our NA and several self-approbations the optimal final version of the manual consisted of 3 units, the content structure of the units can be presented as following:

1. Key phrases of the unit

2. Main text of the unit (adapted, app. 2000 words) for reading, translation into a native language, reproduction, pronunciation and grammar drills

3. Vocabulary of the unit (app. 250 words) 
4. A supplementary authentic text for translation from English into a native language (adapted, app. 1000 words)

5. Role-play of the unit (oral skills development based on the target and GE situations)

6. Supplementary authentic texts for translation from the native language into English (adapted, app. 350 words each)

7. Grammar exercises (word order in affirmative and interrogative clauses; general and special questions; preposition use; etc.)

8. Exercises on comprehensive and rhetoric oral skills development

9. Polylogue, based on the material of the unit (ESP)

10. Oral presentations and discussions of written and video materials.

In our manuals each of the units is powered with two contextspecific enactments, also known as context-specific scenarios or role-plays (RP), in the form of a polylogue presented in English and simultaneously translated into the native language, see Fig. 1.

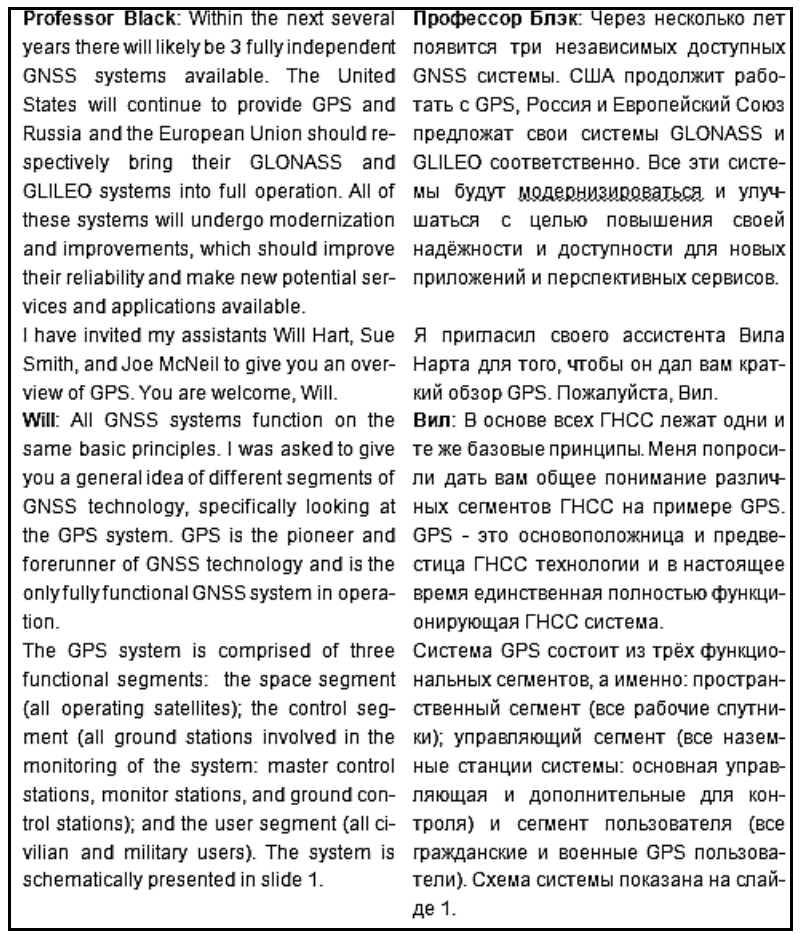

Figure 1. A part of a GE and ESP RP with simultaneous translation into a native language

The first RP of each unit focuses learners' attention on different types of mixed GE and ESP communication, while the second RP is mainly aimed at ESP communication, based on the material of the unit and required in potential work situations. To make the process of lexis learning, revision and assessment more flexible, a special software, enabling learners to learn / revise the new words of the unit (units), and check themselves independently, was developed, see Fig. 2.

Each of the units has a thematic video support developing learners' hearing skills and comprehensive aural understanding of an English speech.

Apart from the 3 main units the manual offers a number of appendices crucial for efficient ESP learning: specially developed grammar section, supporting each of the units with learned or revised material and supplementary examples based on ESP lexis; glossary of terms and acronyms used in scientific literature; rules of pronunciation of arithmetic expressions, formulas, and equations in English; spelling of Greek alphabet in English, see Fig. 3.

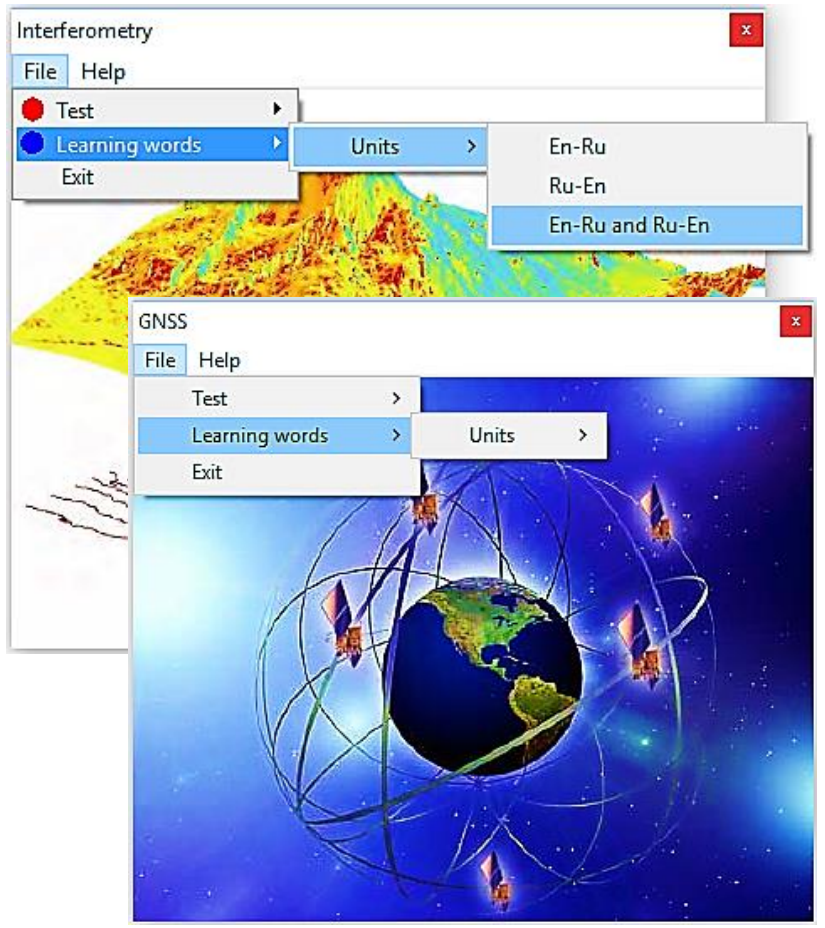

Figure 2. ESP software for learning, revision, and selfassessment

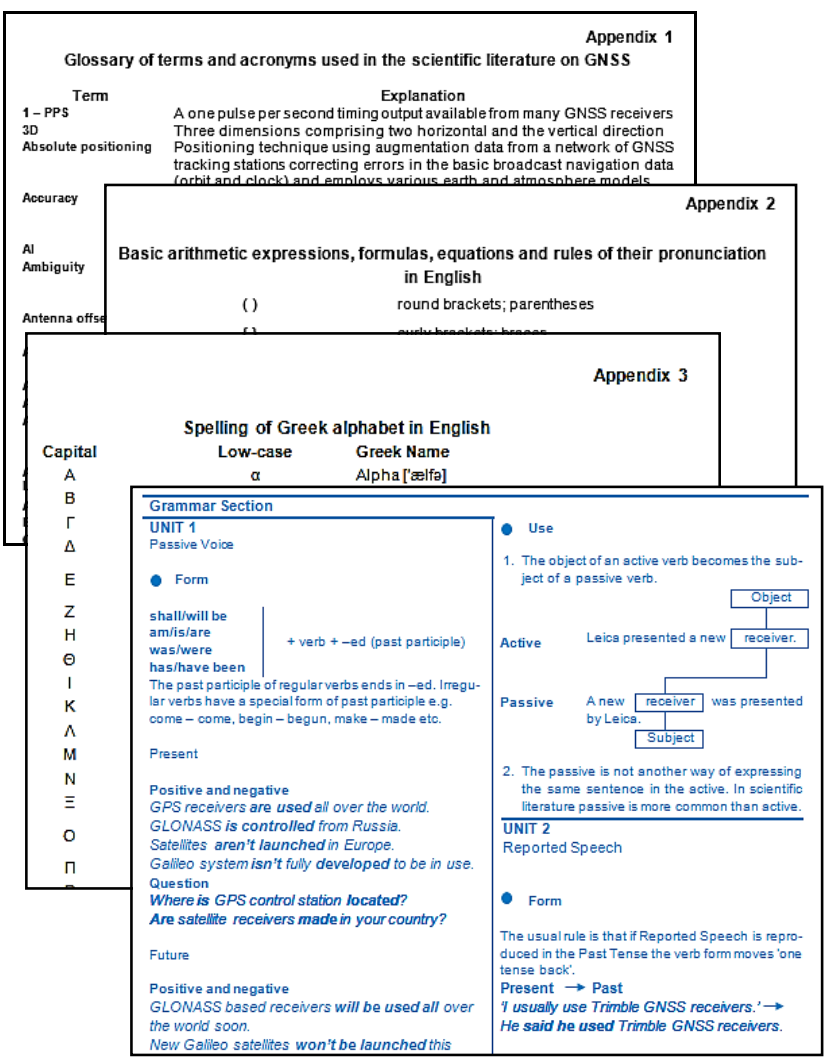

Figure 3. Appendices of the manual

When a tentative version of the manual is ready it is strongly recommended to test it within a small group of learners. As a 
rule, this phase helps to reorganize the ESP learning materials, optimize types of grammar, comprehensive, and communicative exercises, making the final version of the manual much more customized to the learners' needs. Apart from the considerable improvement of the manual this phase makes the ESP teacher much more confident in the field of learners' study.

Developed, approved, and adopted manuals play a focal role in ESP language classroom practices but yet may easily fail to incorporate significant features of the desired outcomes they are supposed to address (Lamie, 1999). Reliance on the manual may distract attention from learners' needs and teaching methods that should be favored in the classroom. For this reason it is essential to understand the principles of ESP manual updating and be aware of teaching methods used for ESP classrooms.

\section{ESP DIDACTICS AND TEACHING METHODS}

Didactics is very much a question of what we want to do in class, then when, why and how we want it to be done. It is a question of planning, structuring, integrating and management of various activities for the purpose of enhancing the learners' attainments.

Bell (2002) and Porcaro (2013) astutely address the question of how much knowledge of the learners' field of study the ESP teacher needs to have to be able to select, adapt, simplify authentic texts and develop the manual that would meet the requirements of the NA, and then teach learners. From our point of view the best solution is to employ an ESP teacher having a technical background relatively close to the field of study, which in many cases is not possible. Majority of ESP practitioners are not experts in the target field of the learners and have to struggle to comprehend materials they require learners to master. Such situations should induce ESP teachers to develop a special relationship with the learners, which should be more equal than in ordinary English language learning settings. In this teacherlearner interaction the first and the second are necessary to each other to make the training process successful: while teachers are considered language experts, learners have related expertise in their own fields.

The idea of practicing language learning in authentic environment is not new (Gregersen \& Madsen, 2009; OffordGray \& Aldred, 1998) and is in line with communicative language approach (CLA) that has been largely used for ESP teaching in recent years. According to practitioners of CLA its most major features are:

1. An emphasis on learning to communicate through interaction in the target language

2. Introduction of authentic texts into the learning situation

3. Provision of opportunities for learners to focus, not only on language but on the learning management process

4. An enhancement of the learner's own personal experiences as important contributing elements to classroom

5. An attempt to link classroom language learning with language activities outside the classroom.

Thus, in our ESP classroom the CLA takes the form of pair and group work requiring negotiation and interaction between learners, communicativeness-based activities that encourage learners to develop their confidence, RPs in which students practice and develop GE and ESP language functions, as well as judicious use of grammar and pronunciation focused activities.

In order to successfully engage ESP teachers with learners, we have implemented a model of three Cs offered by Bell (2002), concerning the performance of the first. The model is presented in Table 2.

\begin{tabular}{|l|l|}
\hline $\begin{array}{c}\text { Features of ESP } \\
\text { teachers }\end{array}$ & \multicolumn{1}{|c|}{ Performance } \\
\hline Curiosity & $\begin{array}{l}\text { ESP teachers should be interested in the } \\
\text { learners' field of study, trying to get as } \\
\text { much knowledge as possible from their } \\
\text { learners } \\
\text { ESP teachers should constantly consult } \\
\text { with subject matter scientists } \\
\text { ESP teachers' confidence will grow as } \\
\text { Confidence }\end{array}$ \\
$\begin{array}{l}\text { about the learners' field of study and } \\
\text { work with specialists }\end{array}$ \\
\hline
\end{tabular}

Table 2. Three Cs model of ESP teacher performance

To get rid of learners' bad habits of unjustified usage of their native language during ESP training, the classroom activities initiated by the teacher should be always carried out in English, apart from those situations when it is legitimately necessary (e.g. explanation of grammar).

Typical classroom routines can be described as follows:

- Warming up exercises when the teacher initiates a short dialogue (polylogue) with learners discussing different GE and ESP topics (lasting no more that 10-12 minutes)

Check of the learned material (e.g. lexis, active set phrases, comprehensive understanding of grammar and sentence structures and so on) can be done orally or in writing (1-2 minutes)

- Introduction to the lesson goals and objectives (1 minute)

- Work on the main text of the unit (reading, answering questions, translation, practicing language and pronunciation skills: repetition drills, transformation drills, substitution drills, question and answer drills ( $15-20$ minutes)

Introduction to grammar of the lesson or its revision, carrying out grammar and comprehensive exercises $(10-15$ minutes $)$

- Organizing learners' work in pairs or small groups: relation / reproduction of the main or supplementary text of the unit enhanced with additional information provided by learners' experience, see table 3; reproduction of RP, reproduction of enlarged / modified RP of the unit, see table 4; work with video situations, see table 5 ; etc. ( $30-90$ minutes)

Work with new material (e.g. grammar exercises, text translation, quizzes) $(10-15$ minutes $)$

- Check of learners' home assignments (10 minutes).

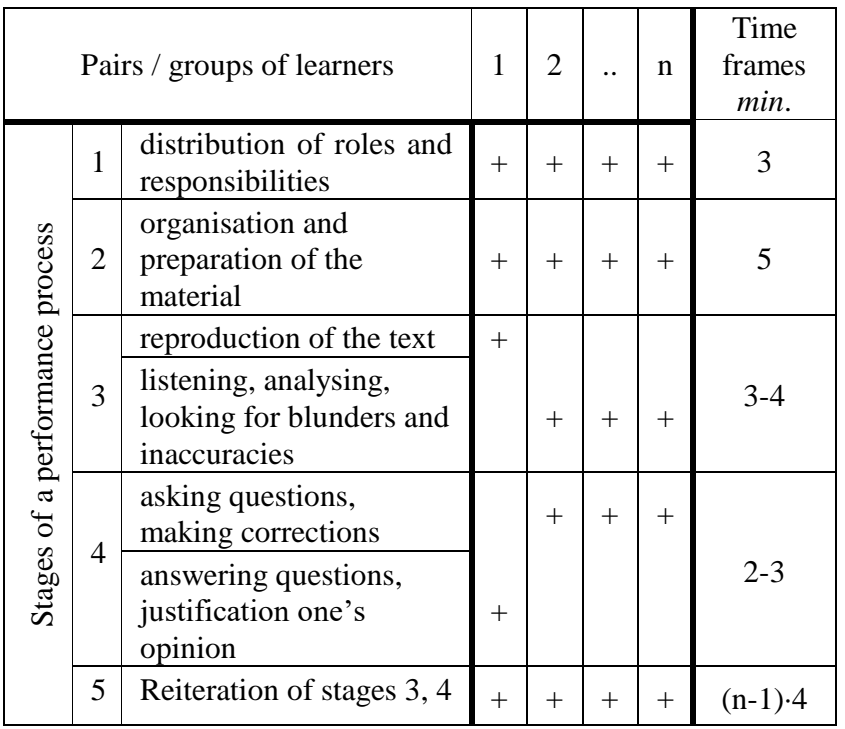

Table 3. Stages and time frames of a text reproduction / relation performance process 
Speaking about ESP teachers' role in pair or group activities of the learners we have to emphasize the need of their alive and thoughtful involvement in all of the processes taking place during the class.

\begin{tabular}{|c|c|c|c|c|c|c|c|}
\hline \multicolumn{3}{|c|}{ Learners } & 1 & 2 & .. & $\mathrm{n}$ & \multirow{2}{*}{$\begin{array}{c}\begin{array}{c}\text { Time } \\
\text { frames }\end{array} \\
\text { min. } \\
90 \\
\end{array}$} \\
\hline \multirow{11}{*}{ 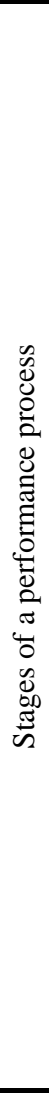 } & \multicolumn{6}{|c|}{ Class 1} & \\
\hline & 1 & $\begin{array}{l}\text { Learning small pieces } \\
\text { ( } 20 \text { - } 30 \text { words) of a RP }\end{array}$ & + & + & + & + & $10-15$ \\
\hline & 2 & $\begin{array}{l}\text { Reiteration of stage } 1 \\
\text { till the end of the RP }\end{array}$ & + & + & + & + & - \\
\hline & 3 & $\begin{array}{l}\text { Reproduction of the } \\
\text { whole RP with open } \\
\text { text }\end{array}$ & + & + & + & + & $4-5$ \\
\hline & 4 & $\begin{array}{l}\text { Reiteration of stage } 3 \\
\text { with gradual decreasing } \\
\text { student's dependence } \\
\text { on the text of the RP }\end{array}$ & + & + & + & + & $5-7$ \\
\hline & 5 & $\begin{array}{l}\text { Reproduction of the } \\
\text { whole RP without open } \\
\text { text }\end{array}$ & + & + & + & + & $4-5$ \\
\hline & 6 & $\begin{array}{l}\text { Reiteration of stage } 5 \\
\text { with gradual } \\
\text { acceleration of the RP } \\
\text { reproduction }\end{array}$ & + & + & + & + & $10-12$ \\
\hline & 7 & $\begin{array}{l}\text { Enlargement or } \\
\text { modification of the RP }\end{array}$ & + & + & + & + & $5-6$ \\
\hline & 8 & $\begin{array}{l}\text { Reproduction of the } \\
\text { whole RP without open } \\
\text { text }\end{array}$ & + & + & + & + & $4-5$ \\
\hline & 9 & $\begin{array}{l}\text { Reiteration of stages } 7 \text {, } \\
8\end{array}$ & + & + & + & + & $10-15$ \\
\hline & 10 & $\begin{array}{l}\text { Distribution of the } \\
\text { roles to be learned in } \\
\text { the groups }\end{array}$ & + & + & + & + & $1-2$ \\
\hline & & Groups & 1 & 2 & .. & $\mathrm{m}$ & $\begin{array}{l}\text { Time } \\
\text { frames } \\
\text { min. }\end{array}$ \\
\hline \multirow{9}{*}{ 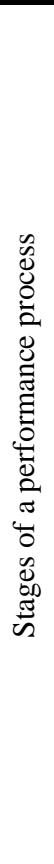 } & \multicolumn{6}{|c|}{ Class 2} & 90 \\
\hline & 11 & $\begin{array}{l}\text { Reproduction of the } \\
\text { whole RP without open } \\
\text { text (stages } 1,2)\end{array}$ & + & + & + & + & $4-5$ \\
\hline & 12 & $\begin{array}{l}\text { Reproduction of the } \\
\text { whole RP without open } \\
\text { text }\end{array}$ & + & + & + & + & $10-15$ \\
\hline & 13 & $\begin{array}{l}\text { Exchange and learning } \\
\text { new of roles of the RP }\end{array}$ & + & + & + & + & $5-10$ \\
\hline & 14 & $\begin{array}{l}\text { Reproduction of the } \\
\text { whole RP without open } \\
\text { text }\end{array}$ & + & + & + & + & $10-15$ \\
\hline & 15 & $\begin{array}{l}\text { Reiteration of stages } 13 \text {, } \\
14\end{array}$ & + & + & + & + & $20-30$ \\
\hline & 16 & $\begin{array}{l}\text { Reproduction of the } \\
\text { whole RP without open } \\
\text { text (stages } 1,2)\end{array}$ & + & + & + & + & $4-5$ \\
\hline & 17 & $\begin{array}{l}\text { Improvisation within } \\
\text { the general plot of the } \\
\text { RP (optional) }\end{array}$ & + & + & + & + & $4-5$ \\
\hline & 18 & $\begin{array}{l}\text { Reproduction of the RP } \\
\text { in random order chosen } \\
\text { by a teacher }\end{array}$ & + & + & + & + & $7-10$ \\
\hline
\end{tabular}

Table 4. Stages and time frames of an RP reproduction process
For instance, see Table 3, when learners work in groups on relation / reproduction of a text, at stage 1 ESP teachers should pay a special attention to the learners' group formation. Each group may be either homogeneous, concerning learners' educational achievements and knowledge of English, or heterogeneous allowing learners to compensate each other's learning deficiencies. The first option enables to organize the workflow of stages 3-6 in such an order that the groups with the least ratio of learning deficiencies are the first in line with the text reproduction / relation allowing the other groups to take into consideration success and failures of the previous groups and make their own reproduction much more immaculate.

As for stages 2-6, ESP teachers should be active but not too persuasive short time players / advisors, keeping in mind that process oriented interaction, where learners work in groups, allows them to learn from each other.

According to our observations and recent research (Talberg, 2006; Tasić, 2009; Porcaro, 2013) learners like being involved in active oral communication when working with videos, RP, or making oral presentations (in groups or individually) on technical subjects. Other than development of learners' oral skills all of the mentioned above activities involve writing, reflection and structuring, graphic design and presentation layout, which are also an integral part of the developing language competences.

\begin{tabular}{|c|c|c|c|c|c|c|c|}
\hline & & Learners / groups & 1 & 2 & .. & $\mathrm{n}$ & $\begin{array}{l}\text { Time } \\
\text { frames } \\
\text { min. }\end{array}$ \\
\hline & & Version 1 & & & & & $15-20$ \\
\hline$\tilde{b}$ & 1 & $\begin{array}{l}\text { Listening and watching } \\
\text { the video in English } \\
\text { (looking for: answers to } \\
\text { previously given } \\
\text { questions; errors in the } \\
\text { handouts etc.) }\end{array}$ & + & + & + & + & $3-5$ \\
\hline 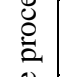 & 2 & $\begin{array}{l}\text { Answering the } \\
\text { questions, discussions }\end{array}$ & + & + & + & + & $1-2$ \\
\hline $\begin{array}{l}\mathscr{U} \\
\stackrel{\Xi}{\Xi}\end{array}$ & 3 & $\begin{array}{l}\text { Short relation of the } \\
\text { video }\end{array}$ & + & + & + & + & $2-3$ \\
\hline 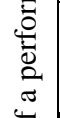 & 4 & $\begin{array}{l}\text { Reproduction of the } \\
\text { video with the switched } \\
\text { off sound }\end{array}$ & + & + & + & + & $7-10$ \\
\hline 0 & & Version 2 & & & & & $15-20$ \\
\hline 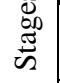 & 1 & $\begin{array}{l}\text { Watching the video } \\
\text { with no sound }\end{array}$ & + & + & + & + & $2-3$ \\
\hline & 2 & $\begin{array}{l}\text { Scripting one's own } \\
\text { version of the video }\end{array}$ & + & + & + & + & $4-5$ \\
\hline & 3 & $\begin{array}{l}\text { Discussions of the } \\
\text { scripts }\end{array}$ & + & + & + & + & $5-6$ \\
\hline & 4 & $\begin{array}{l}\text { Performance of stages } \\
1-3 \text { of Version } 1\end{array}$ & + & + & + & + & $5-6$ \\
\hline
\end{tabular}

Table 5. Stages and time frames of work with video materials

ESP teachers should pay an appropriate attention to make their learners be constantly involved in educational activities all the time they are in the classroom. Each of the learners must be firmly convinced those 90 minutes of the class the teacher is working with him, and only him, personally. All of the classroom activities also need to be limited in time. The time for each activity may be calculated as 1.3 or 1.5 of the ESP teacher's time required to perform the same operations; the ratio depends on an ESP teacher experience (Musikhin, 2013). Being under time constraint the learners will be motivated to improve 
their organizational and language skills in order not to be a hindrance to work of others.

To develop creativity and skills of independent work an ESP teacher should prepare home assignments for the learners thoroughly (e.g. making presentations, developing a group RP on a particular topic; reasoned presentation of one's vision of the studied material, etc.).

It is necessary to point out that after each class learners should be given an assignment, and then, if given, checked and assessed without fail.

\section{UPDATING THE MANUAL}

To make the ESP manual correspond to the dynamically changing learners' needs and evolutions taking place in their field of study its learning materials (e.g. authentic texts, RP, lexis and exercises) must be updated constantly. In our work we describe a research technique that enables to combine the learning process with updates of the manual.

The technique allows an ESP teacher and the learners to be active players in the preliminary search, selection and customization of advanced materials presented in current research and scientific literature. Such approach is highly efficient and a contributing factor that makes the ESP teacher much more confident with the adopted materials when teaching them to the next group of learners.

The main idea of the technique is to involve current learners in the search and analysis of the cutting-edge research taking place in their field of study and then include this information into classroom assignments and activities. Typical tasks that learners are usually involved in are: search for new information, its analysis, completing specialized technical vocabulary and new sets of key phrases, designing their own comprehensive and grammar exercises. As a result by the end of the ESP course the teacher has up-to-date materials that need some minor refinement and customization. Then the new set of learning materials replaces outdated or irrelevant matters of the manual. In our work on ESP courses the annual proportion of the updated materials was ranging from 12 to $31 \%$, see Table 6 .

\begin{tabular}{|l|c|c|c|c|}
\hline \multirow{2}{*}{ ESP course } & \multicolumn{4}{c|}{ Percentage of updates } \\
\cline { 2 - 5 } & $\begin{array}{c}201 \\
2\end{array}$ & 2013 & $\begin{array}{c}201 \\
4\end{array}$ & 2015 \\
\hline SAR Interferometry & - & 12 & 15 & 13 \\
\hline $\begin{array}{l}\text { Remote Sensing and } \\
\text { Digital Photogrammetry }\end{array}$ & - & - & 28 & 19 \\
\hline GNSS Technologies & - & - & - & 31 \\
\hline
\end{tabular}

Table 6. Percentage of annual updates of the ESP manuals

The software source files with active vocabulary and key phrases of the units may be easily rearranged in any text editor. Since all learning materials (tasks, exercises, and interactive user interface of the software) presented in English one more advantage of the developed manuals is that they may be easily customized for teaching ESP to learners from other countries. In this case the only thing that needs to be done is to provide the manual with the translation of the vocabulary and key phrases from English into another native language.

\section{CONCLUSION}

The role of English in the fields of science and engineering is ever increasing. Consequently, so too are the demands to ESP manuals to serve the needs of learners (students and professionals) in their fields of study to conduct research and communication activities in English on an international scale. Offering learners the opportunity to develop adequate and comprehensive English skills is becoming a necessity. The incorporation of language and communication improvement courses and ESP manuals is an important element of continuous learning, and will eventually contribute to the process of lifelong learning.

This paper concerned the following:

1. Describes a successful four-year experience in the development of ESP manuals in SAR Interferometry, Remote Sensing and Digital Photogrammetry and GNSS Technologies, supported with specially developed software and thematic videos

2. Addresses the practical points of ESP course design and implementation

3. Offers a set of key teaching methods and didactic approaches that proved to be most efficient in ESP language training

4. Describes a research technique enabling the organization of simultaneous active learning and updating of the ESP manuals.

We hope that the paper will serve to stimulate and guide other teachers into this important and exciting area.

\section{ACKNOWLEDGEMENTS}

This research was supported by 2011 IYIF 'Interra' funded by Administration of Novosibirsk Region (grant number 07-062011-12N)

I also wish to thank my three anonymous referees for critique, helpful comments and suggestions on an earlier version of this paper.

\section{REFERENCES}

Bell, D., 2002. Help! I've been asked to teach a class on ESP! IATEFL Issues 169.

Bolton, K., 2008. English in Asia, Asian Englishes, and the issue of proficiency. English Today 94, Vol. 24, No. 2, 3-12.

Gregersen, A., Madsen, L., 2009. Teaching in English at engineering programs in Danish universities, Denmark http://www.sefi.be/wp-content/abstracts2009/Gregersen.pdf (11 Sep. 2015).

Kim, H. H., 2013. Needs Analysis for English for Specific Purpose course Development for Engineering Students in Korea. International Journal of Multimedia and Ubiquitous Engineering. Vol. 8, No. 6 (2013), pp. 279-288.

Kitao, K., 1996. Why Do We Teach English? The Internet TESL Journal, Vol. II, No. 4, April 1996 http://iteslj.org/Articles/Kitao-WhyTeach.html (21 May 2014).

Lamie, J. M., 1999. Making the Textbook More Communicative. The Internet TESL Journal, Vol. V, No. 1, January 1999 http://iteslj.org/Articles/Lamie-Textbooks.html (24 Nov. 2014).

Long, M. H., 2005. Methodological issues in learner needs analysis, Long M. H. (ed.) Second Language Needs Analysis, Cambridge: Cambridge University Press, (2005), pp. 19-76.

Musikhin, I. A., 2013. Course of Practical Pedagogics and Psychology for Beginner Teachers. Novosibirsk, Siberian State Academy of Geodesy, (2013), 231 p. 
Offord-Gray, C., Aldred, D., 1998. A Principled Approach to ESP Course Design. Hong Kong Journal of Applied Linguistics, Vol. 3, No. 1, June 1998, pp. 77-86.

Ono, Y. A., Morimura, K., 2007. Effective Methods for Teaching Technical English to Japanese Engineering Students: Case Study at School of Engineering, The University of Tokyo, Professional Communication Conference, 2007. IPCC 2007. IEEE International, Oct. 2007, pp.1,7, 1-3.

Porcaro, J. W., 2001. Integrating authentic materials and language skills in English for Science and Technology instruction. English Teaching Forum 39 (2): 30-32.

Porcaro, J. W., 2013. Teaching English for Science and Technology: An Approach for Reading with Engineering English. English Teaching Forum, No.2, pp. 32-38.

Riemer, M. J., 2002. English and Communication Skills for the Global Engineer. Global Journal of Engineering Education, Vol. 6, No. 1, pp. 91-100.

Talberg, O., 2006. Teaching EFL for Engineering Students. $9^{\text {th }}$ International Conference on Engineering Education, San Juan, July 23-28, 2006. http://ineer.org/Events/ICEE2006/papers/ 3124.pdf (26 Aug. 2015).

Tasić, M., 2009. English Language Teaching in Mechanical Engineering. FACTA UNIVERSITATIS. Linguistic and Literature, Vol. 7, No. 1, 2009, pp. 101-112. http://facta.junis. ni.ac.rs/lal/lal2009/lal2009-08.pdf (28 Dec. 2013).

West, R., 1994. Needs analysis in language teaching. Language Teaching, Vol. 26. No. 1, pp. 1-9. 